\title{
The Effect of Emotional Intelligence and Work Life Balance on Organizational Citizenship Behavior with Career Development as Mediating Variable (A Case Study at PT. Bank Pembangunan Daerah (BPD) Head Office and Main Branch, Padang)
}

\author{
Nur' Afni ${ }^{1}$, Syamsul Amar ${ }^{2 *}$ \\ ${ }^{1}$ Padang State University, Padang and Indonesia, $\square$ afni0602@gmail.com \\ 2Padang State University, Padang and Indonesia, $\bowtie$ syamsul amar3@yahoo.com \\ *Corresponding Author
}

\begin{abstract}
This study aims to analyze the effect of emotional intelligence and work life balance on organizational citizenship behavior with career development as mediating variable at PT. Bank Pembangunan Daerah (BPD) Head Office and Main Branch, Padang. This study uses quantitative descriptive method with primary and secondary data obtained through observation, interviews, and questionnaires to 195 employees as respondents. The data analyzed by Path Analysis using SPSS software. The result shows that emotional intelligence and work life balance has a significant effect on career development. Moreover, career development, emotional intelligence, and work life balance also have significant effect on organizational citizenship behavior. Few studies have discussed on direct effect of single variable (e.g. emotional intelligence, work life balance, career development) on organizational citizenship behavior. However, this is the first study to investigate career development as mediating variables that play the effect of emotional intelligence and work life balance on organizational citizenship behavior. Emotional intelligence and work life balance are treated as independent variables and organizational citizenship behavior as the dependent variable and career development as mediating variables.
\end{abstract}

Keywords: emotional intelligence, work life balance, career development, organizational citizenship behavior

\section{Introduction}

Organizations have various kinds of resources as 'inputs' to be transformed to 'output' in the form of goods or services. These resources include capital or money, technology to support the production process, methods or strategies used to operate, humans and so on. Among these resources, human resource is the most important elements. Organizational citizenship behavior is the role of employees beyond their job description in order to support the effectiveness of organizational activities.

Robbins (2007) suggests that organizational citizenship behavior is a choice behavior that is not part of an employee's formal work obligations, but supports the organization's function effectively. A person with a high organizational citizenship behavior demonstrates helping behavior towards others although it is not their duties and obligations. Jobs that are dealing directly with community requires employees who have high organizational behavior as at times they will need to provide services that are beyond their formal obligations but necessary to ensure achievement of organization's goals. Employees who have voluntary behavior and good mutual help tend to have good performance. Employees who work above the standards set by the company and never show complaints in work are also indicators of organizational citizenship behavior .

Career development is planning and management process to improve the career path of employees so that they have the ability to work and play an important role in the organization. More career 
development translates to employees always try to do positive and beneficial things for the company that will support the creation of organizational citizenship behavior. Duffy (2007) defines career development as a job title that slowly rises with the promotion or call from the company for a higher position.

This statement is supported by research conducted by Erika (2018) stating that there is a Career Development that has a significant effect on organizational citizenship behavior), with the level of sig. smaller than the Alpha value $(0,000<0,05)$ and $t$ count $>t$ table $(4,679>1,989)$. Research conducted by Sutton (2005) also found that career development has a relationship with organizational citizenship behavior.

Emotional intelligence is the ability to recognize one's own feelings and those of others, the ability to motivate oneself and the ability to manage emotions in oneself and in relation to others (Daniel Goleman, 2001). Emotional Intelligence can determine organizational citizenship behavior on employees. Employees who can understand, control and use their emotions effectively, are able to create positive behaviors that can increase organizational citizenship behavior.

This statement supported by research conducted by Mojtaba Rafiei (2017)shows that Emotional Intelligence has an effect on organizational behavior of hospital staff. In addition, the research conducted by Ibrahim (2013) also found that Emotional Intelligence has a significant effect on organizational citizenship behavior nurses at Anutapura General Hospital and Undata Hospital in Palu.

According to Weckstein (2008) Work life balance is a concept of balance that involves ambition or career with happiness, leisure, family, and spiritual development. Employees who have a good working life balance tend to have good organizational citizenship behavior. Work life balance is a condition for creating a balance between one's working life and personal life. The more balanced work life and personal life of a person will make a person's life to be controlled and qualified so that it can create organizational citizenship behavior.

This is in line with the research conducted by Rabindra (2016) which states that significant effects of work life occur balancing organizational citizenship behavior. In this case, the level of organizational citizenship behavior is effected by the balance of work life balance. Research conducted by Prasetio (2016) found that there was an effect of work life balance on organizational citizenship behavior.

This study aims to analyze the effect of emotional intelligence and work life balance on organizational citizenship behavior with career development as a mediation variable. Based on the background described above, the problem are classified into five sections; (1) How is the effect of emotional intelligence on career development? (2) How is the effect of work life balance on career development? (3) How is the effect of career development on organizational citizenship behavior? (4) How is the effect of emotional intelligence on organizational citizenship behavior? (5) How is the effect of effect of work life balance on organizational citizenship behavior?

\section{Literature and Hypotheses}

\section{Emotional Intelligence on Career Development}

According to Daniel Goleman (2001), Emotional Intelligence is the ability to recognize our own feelings and other people's feelings, the ability to motivate theirself and the ability to manage emotions very well in ourselves and in relationships with others. Hadizadeh Moghadam, A. and Farajeeyan (2008) states that Emotional Intelligence is considered as the ability to understand and manage people in human relations

Daniel Goleman (2001) suggests that there are five indicators that can measure the level of one's Emotional Intelligence, Self Awareness, Self-Mastery, Motivation, Recognizing other people's emotions (empathy) and Social Skills.

Duffy (2007) defines career development as a job title that slowly rises with the promotion or call from the company for a higher position. Career Development Indicators that will be looked into is in terms of 
career planning (Siagian, 2012). In this case, the indicators used consist of five points, namely fair treatment in a career, concern for direct supervisors, information about various promotional opportunities, interests to be promoted and levels of satisfaction.

Emotional Intelligence affects career development. An employee who has good Emotional Intelligence will be able to understand and manage the emotions of himself and others. Therefore in carrying out the duties and responsibilities assigned by the company, he will be able to choose, sort and control his emotions and other colleagues'. Employees who have high emotional intelligence will try to do their tasks and responsibilities as well as possible, In turn, it will support the his/her career development .

Evidence of research shows that by creating an emotionally intelligent workplace, organizations have been able to truly drive performance and careers in organizations (Carmeli, A., \& Josman, 2006). As a result, organizations have begun to redefine norms to deal with employee careers and promotions. In addition, research conducted by Kunnanatt (2008) found that people who get along like those with high emotional Intelligence tend to have an advantage over those who have lower Emotional Intelligence levels.

\section{H1: Emotional Intelligence has a significant effect on career development}

\section{Work Life Balance on Career Development}

According to Lockwood, (2003) work life balance is a balanced state in two demands where the work and life of an individual are the same. Where work-life balance in the employee's view is the choice to manage work and personal obligations or responsibilities to the family. Greenhaus et.al (2003) state that work-life balance is the degree to which an individual is bound together in work and family, and is equally satisfied with the role in work and role in his family. In line with that, according to Weckstein (2008) Work life balance is a concept of balance that involves ambition or career with happiness, leisure, family, and spiritual development.

Hudson (2005) states that work life balance has three components of balance namely time balance, balance of engagement, and balance of satisfaction. Not infrequently employees have now realized how important work life balance is so they want a type of work that is more flexible in terms of time so that they can work without ignoring his personal life. The balance between life in work (work life balance) is an important factor that needs to be considered by companies in making a policy so that work productivity is maintained. Work life balance can affect one's career development. The more balanced work life and personal life of a person will make the person comfortable in doing work that will create good relationships and involvement. So that with the intensity of the relationship and good involvement, the greater the career opportunity increases. The above statement is supported by the results of research conducted by Caroline Straub (2007) stating that there is a positive effect between work life balance and career development especially among women.

\section{H2: Work life balance has a significant effect on career development}

\section{Career Development on Organizational Citizenship Behavior}

Robbins (2007) argues that organizational citizenship behavior is a choice behavior that is not part of an employee's formal work obligations, but supports the organization's functions effectively. Robbins \& Judge (2008) re-launches a book on Organizational citizenship behavior which defines organizational citizenship behavior as a choice behavior that is not part of an employee's formal work obligations, but supports the functioning of the organization effectively.

According Organ (2006) organizational citizenship behavior consists of five dimensions as follows. Altruism, that is, behavior helps alleviate the work shown to other individuals in an organization, such as helping unhealthy coworkers. Courtesy, namely helping work colleagues prevent problems related to their work by giving consultation and information and respecting their needs, or understanding and 
empathizing even when criticized. Sportsmanship, namely tolerance to situations that are not ideal in the workplace without complaining, for example taking part in the failure of the project team might succeed by following the advice of members.Civic virtue, which is involved in organizational activities and concerned with the survival of the organization, for example, is willing to represent the company for a joint program. Conscientiousness, which is doing things that benefit the organization, for example by complying with regulations in the organization and being willing to overtime projects.

Career development is planning and management process to improve the career path of employees so that they have the ability to work and play an important role in the organization More career development translates to employees always try to do positive and beneficial things for the company that will support the creation of organizational citizenship behavior.

This is supported by research conducted by by Erika (2018)stating that there is a career development that has a significant effect on organizational citizenship behavior), with the level of sig. smaller than the Alpha value $(0,000<0,05)$ and $t$ count $>t$ table $(4,679>1,989)$. Research conducted by Sutton (2005) also found that career development has a relationship with organizational citizenship behavior

\section{H3: Career development has a significant effect on organizational citizenship behavior}

\section{Emotional Intelligence on Organizational Citizenship Behavior}

Emotional Intelligence can determine organizational citizenship behavior on employees. Employees who can understand, control and use their emotions effectively, they will be able to create positive behaviors that can increase organizational citizenship behavior.

Research conducted by Mojtaba Rafiei (2017) shows that Emotional Intelligence has an effect on the organizational behavior of hospital staff. In addition, the research conducted by Ibrahim (2013) also found that Emotional Intelligence has a significant effect on nurses' organizational citizenship behavior at Anutapura General Hospital and Undata Hospital in Palu. The increased in nurses' ability to motivate themselves accompanied by high self-awareness, will be followed by an increase in nurses' organizational citizenship behavior related to altruism and conscientious attitudes.

\section{H4: Emotional Intelligence has a significant effect on organizational citizenship behavior}

\section{Work Life Balance on Organizational Citizenship Behavior}

Employees who have a good working life balance tend to have good organizational citizenship behavior. Work life balance is a condition for creating a balance between one's working life and personal life. The more balanced work life and personal life of a person will make a person's life to be controlled and qualified so that it can create organizational citizenship behavior.

This is in line with the research conducted by Rabindra (2016) which states that significant effects of work life occur balancing organizational citizenship behavior. In this case, the level of organizational citizenship behavior is affected by the balance of work life balance. Research conducted by Prasetio (2016) found that there is an effect of work life balance on organizational citizenship behavior.

H5: Work life balance has a significant effect on organizational citizenship behavior

\section{Methods}

\section{Research Procedure}

This study focuses on the effect of emotional intelligence and work life balance on organizational citizenship behavior with career development as mediating Variable at PT. Bank Pembangunan Daerah (BPD) Head Office and Main Branch, Padang. Emotional intelligence and work life balance are treated as independent variables and organizational citizenship behavior as the dependent variable and career development as mediating variables. 
This study uses quantitative descriptive method with primary and secondary data obtained through observation, interviews, and questionnaires to 195 employees as respondents. The data will be analyzed by Path Analysis using SPSS software.

\section{Population and Samples}

The population for this study comprised of the employees working at PT. Bank Pembangunan Daerah (BPD) Head Office and Main Branch, Padang, amounting to 380 employees. The sampling technique used is proportional cluster random sampling where members of the population chosen randomly and in groups proportionally, the choice of samples is done through simple random technique. The sample size is determined using the Slovin formula with an error rate of $5 \%$, Therefore, the sample size of the study was 195 employees.

\section{Results and Discussions \\ Emotional Intelligence Variables}

Based on data analysis, the average level of respondents' achievement on emotional intelligence is $72.47 \%$. The highest level of respondents' achievement is $84.10 \%$, which means that employees of PT. Bank Pembangunan Daerah (BPD) Head Office and Main Branch, Padang can understand their own feelings well. Furthermore, the lowest level of respondents' achievement is $65.54 \%$. In overall, the respondents' achievement on emotional intelligence can be categorized as sufficient. This proves that emotional intelligence of PT. Bank Pembangunan Daerah (BPD) Head Office and Main Branch, Padang needs to be improved in order to be able to provide good performance for the company.

\section{Work Life Balance variables}

Data analysis suggests that the average level of achievement of respondents on Work Life Balance is $76.8 \%$. The highest level of respondents' achievement is $83.7 \%$, which means that employees of PT. Bank Pembangunan Daerah (BPD) Head Office and Main Branch, Padang have a sense of responsibility for their work. Furthermore, the lowest level of respondents' achievement is $63.20 \%$.

Generally, respondents' achievement on work life balance can be categorized quite well. This however suggests that work life balance of employees at PT. Bank Pembangunan Daerah (BPD) Head Office and Main Branch, Padang has room for improvement on work life balance to ensure achievement of company's goals.

\section{Career Development Variables}

Data analysis suggests that the average level of achievement of respondents on career development is $75.71 \%$. The highest level of respondents' achievement is $80.72 \%$, this means that employees of PT. Bank Pembangunan Daerah (BPD) Head Office and Main Branch, Padang have a great interest in continuing to develop careers in the company. Furthermore, the lowest level of respondents' achievement is $69.33 \%$. In overall, respondents' achievement on career development can be categorized as sufficient. This however suggests that of PT. Bank Pembangunan Daerah (BPD) Head Office and Main Branch, Padang has room for improvement on career development in order to be able to achieve the company's vision and mission.

\section{Organizational Citizenship Behavior Variables}

Data analysis suggests that the average level of achievement of respondents on organizational citizenship behavior is $77.6 \%$. The highest level of respondents' achievement is $82.8 \%$, which means that employees of PT. Bank Pembangunan Daerah (BPD) Head Office and Main Branch, Padangare trying not to create problems with coworkers. Furthermore, the lowest level of respondents' achievement is $72.5 \%$. In overall, respondents' achievement on organizational citizenship behavior can be categorized as sufficient. This however suggests that PT. Bank Pembangunan Daerah (BPD) Head Office and Main Branch, Padang has room for improvement on organizational citizenship behavior in order to have high productivity so that they can realize the company's vision and mission. 


\section{Normality Test}

Based on the results of normality testing using kolmogrovsmirnov, the value of Asymp. Sig. (2-tailed) was 0.200 and the value was significant. Significant because the kolmogrov-smirnov value is greater than $\alpha=0.05$. Thus the data for each variable is normally distributed and can be used for path analysis.

\section{Assumption of Homogeneity Test}

Based on the results of homogeneity testing it can be seen that the significant value of 0.281 on the emotional intelligence variable (X1) is more than 0.05 , it can be concluded that the distribution of variable data is homogeneous, the significance of 0.796 in the work life balance (X2) variable is more than 0.05 it can be concluded that the distribution of variable data is homogeneous, and 0.309 in the career development variable (X3) is more than 0.05 , it can be concluded that the distribution of variable data is homogeneous. Based on this value it can be explained that the distribution of data comes from homogeneous samples, so the results of this study can be analyzed by path analysis.

\section{Path Analysis}

Sub structure 1 (Emotional Intelligence on Career Development and Work Life Balance on Career Development)

In this study the first analysis carried out was looking at the effect of emotional intelligence (X1), work life balance (X2) on career development (X3). The effect of emotional intelligence, work life balance on career development can be seen on the following table:

Table 1 Analysis on the efect of Emotional Intelligence on Career Development and Work Life Balance on Career Development

\section{Coefficients ${ }^{a}$}

\begin{tabular}{|c|c|c|c|c|}
\hline \multicolumn{5}{|c|}{ Coefficients $^{a}$} \\
\hline \multirow{2}{*}{\multicolumn{2}{|c|}{ Model }} & Standardized Coefficients & \multirow[b]{2}{*}{$\mathrm{t}$} & \multirow[b]{2}{*}{ Sig. } \\
\hline & & Beta & & \\
\hline \multirow[t]{3}{*}{1} & (Constant) & & 7,289 &, 000 \\
\hline & Emotional Intelligence & ,177 & 2,123 & ,035 \\
\hline & Work Life Balance & ,187 & 2,237 & 026 \\
\hline
\end{tabular}

R Square $=0.104$

a. Dependent Variable: Pengembangan Karir

From the table above, a partial test can be performed on the causal variable for the following variables: Path coefficient Px3x1 = 0, 177. Based on the data analysis, it shows that the emotional intelligence variable is positive at 0.177 which translates to an increase in career development. $P \times 3 \times 2$ path coefficient $=$ 0.187. This shows that the work life balance variable is positive at 0.187 which will improve career development. Consecutively, the effect of other variables on career development variables, $\mathrm{R}$ Square $=$ 0.104. thus the effect of other variables is as follows:

Value e $=\sqrt{ } 1-\mathrm{R}$ Square

$=\sqrt{ } 1-0,104$

$=0.89$

it can be said that the contribution of other variables outside the Career Development was 0.89 (89\%).

Sub structure 2 (Emotional Intelligence on Organizational Citizenship Behavior, Work Life Balance on Organizational Citizenship Behavior, and Career Development on Organizational Citizenship Behavior.

This second sub-structure analysis discusses the effect of emotional intelligence on organizational citizenship behavior, work life balance on organizational citizenship behavior and career development on organizational citizenship behavior. The results of path analysis obtained the following values: 
Table 2 Analysis on the effect of Emotional Intelligence on Organizational Citizenship Behavior, Work Life Balance on Organizational Citizenship Behavior, and Career Development on Organizational Citizenship Behavior

\begin{tabular}{|c|c|c|c|c|}
\hline \multicolumn{5}{|c|}{ Coefficients $^{a}$} \\
\hline \multirow{2}{*}{\multicolumn{2}{|c|}{ Model }} & Standardized Coefficients & & \\
\hline & & Beta & $\mathrm{t}$ & Sig. \\
\hline \multirow[t]{4}{*}{1} & (Constant) & & 5,596 &, 000 \\
\hline & Emotional Intelligence & 159 & 2,111 & , 036 \\
\hline & Work Life Balance & 219 & 2,900 & ,004 \\
\hline & Career Development &, 526 & 8,167 & , 000 \\
\hline
\end{tabular}

R Square $=0,291$

a. Dependent Variable: OCB

From the table above, a partial test can be performed on the causal variables for the variables as follows: pyx 1 path coefficient $=0.159$. These data shows that the coefficient value of the emotional intelligence variable is positive at 0.159 which will increase the behavior of organizational citizenship behavior. Pyx2 path coefficient $=0.219$. Data analysis shows that the work life balance variable is positive at 0.219 which will increase the behavior of organizational citizenship behavior. Pyx3 path coefficient $=$ 0.526. Based on the analysis of the data shows that career development variables are positive at 0.529 which will improve the behavior of organizational citizenship behavior. Consecutively, the effect of other variables on the organizational citizenship behavior $(\mathrm{ocb})$ variable, the value of $\mathrm{r}$ square $=0.291$. Thus the effect of other variables is as follows:

$$
\begin{aligned}
\text { Pye1 }) & =\sqrt{ } 1-\mathrm{r} \text { square } \\
& =\sqrt{ } 1-0,291 \\
& =0.709
\end{aligned}
$$

it can be said that the contribution of other variables outside the organizational citizenship behavior variable was $0.709(70.9 \%)$

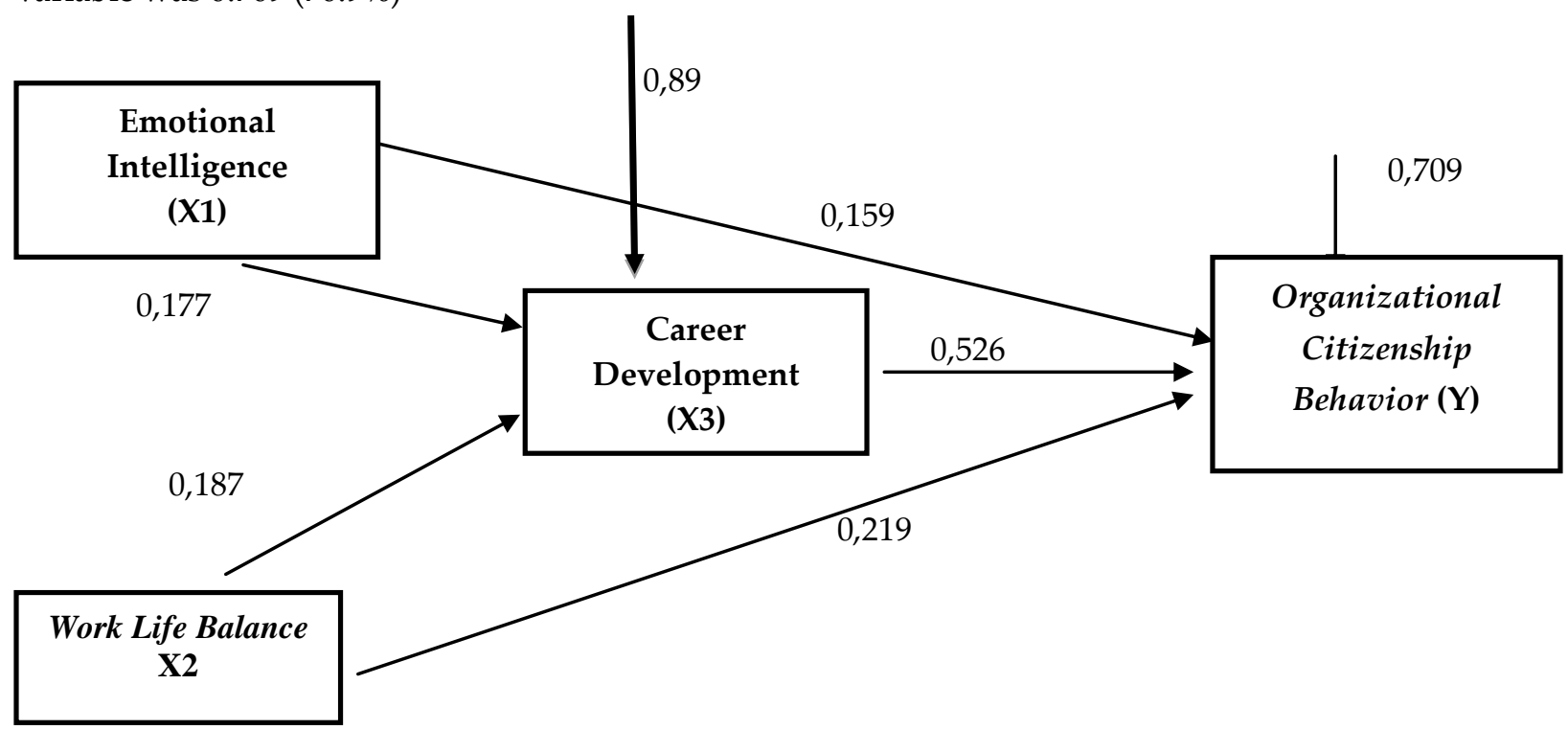

Figure 1

Path Structure of The effect of Emotional Intelligence and Work Life Balance on Organizational Citizenship Behavior with Career Development as a Mediation Variable 


\section{Test F (Simultaneous)}

\section{Structure 1 (Emotional Intelligence and Work Life Balance on Career Development)}

Based on the F-test obtained $\mathrm{f}$ count of 11,174 while the $\mathrm{F}$ table for this study was 3.07. If $\mathrm{F}$ count is large from $\mathrm{f}$ table, there is a simultaneous effect between emotional intelligence variables and work life balance on career development. Significance value of $0,000(0,000<0,05)$, so that it can be interpreted that emotional intelligence and work life balance variables, together (simultaneously) has significant effect on career development variables.

Structure 2 (Emotional Intelligence, Work Life Balance and Career Development on Organizational citizenship behavior)

Based on the F-test obtained $\mathrm{f}$ count of 26,112 while the $\mathrm{f}$ table for this study amounted to 2,60 . If $\mathrm{f}$ count is large from $\mathrm{f}$ table, there is a simultaneous effect between emotional intelligence variables, work life balance and career development on organizational citizenship behavior . Significance value of 0,000 $(0,000<0,05)$, so that it can be interpreted that emotional intelligence variables, work life balance and career development together (simultaneous) has significant effect on organizational citizenship behavior variables.

\section{Partial Test}

To determine whether the hypothesis submitted can be accepted or rejected can be seen from the value of $t$ count, with the criteria:

$\mathrm{t}$ count $>\mathrm{t}$ table or sig $<0.05$ so $\mathrm{H} 0$ is rejected

$t$ count $<\mathrm{t}$ table or sig $>0.05$ then $\mathrm{H} 0$ is accepted

\section{H1: Emotional Intelligence has a significant effect on career development}

Based on the $t$ test, emotional intelligence has a $t$-value of 2.123 with a significance of 0.035 (0.035 $<0.05)$. This shows that emotional intelligence has a significant effect on career development at PT. Bank Pembangunan Daerah (BPD) Head Office and Main Branch, Padang. This case shows that the better employee's emotional intelligence, the better employee's career development. In other words, in this study emotional intelligence has an effect on career development, so that hypotheses are accepted.

H2: Work Life Balance has a significant effecton career development

Based on the $t$ test, work life balance has a $t$ value of 2.237 with a significance of $0.026(0.026<0.05)$. This shows that work life balance has a significant effect on career development at PT. Bank Pembangunan Daerah (BPD) Head Office and Main Branch, Padang. This case shows that the better employee's work life balance, the better employee's career development. In other words, in this study emotional intelligence has an effect on career development, so that hypotheses are accepted.

H3: Career development has a significant effect on organizational citizenship behavior

Based on the $t$ test, career development has a $t$ value of 8.167 with a significance of $0,000(0,000<0,05)$. This shows that career development has a significant effect on organizational citizenship behavior at PT. Bank Pembangunan Daerah (BPD) Head Office and Main Branch, Padang. This case shows that the better employee's career development, the better employee's organizational citizenship behavior. In other words, in this study career development has an effect on organizational citizenship behavior, so that hypotheses are accepted.

H4: Emotional Intelligence has a significant effect on organizational citizenship behavior

Based on the $t$ test, emotional intelligence has a $t$ value of 2.111 with a significance of $0.036(0.036$ $<0.05)$. This shows that emotional intelligence has a significant effect on organizational citizenship behavior at PT. Bank Pembangunan Daerah (BPD) Head Office and Main Branch, Padang. This case shows that the better employee's emotional intelligence, the better employee'sorganizational citizenship 
behavior. In other words, in this study emotional intelligence has an effect on organizational citizenship behavior, so that hypotheses are accepted.

\section{H5: Work life balance has a significant effect on organizational citizenship behavior}

Based on the $t$ test, work life balance has a $t$ value of 2,900 with a significance of $0.004(0.004<0.05)$. This shows that work life balancehas a significant effect on organizational citizenship behavior at PT. Bank Pembangunan Daerah (BPD) Head Office and Main Branch, Padang. This case shows that the better employee's work life balance, the better employee'sorganizational citizenship behavior. In other words, in this study work life balance has an effect on organizational citizenship behavior, so that hypotheses are accepted.

\section{The Effect of Emotional Intelligence (X1) on Career Development (X3).}

Each individual has an emotional capacity within him/her, he/she is required to be able to recognize his/her emotions, manage emotions, motivate himself/herself, get to know the emotions of others, and build relationships with others in facing the demands and expectations of the surrounding environment. Emotional intelligence is the intelligence possessed by each individual. This intelligence is used by individuals when carrying out social interactions, carrying out certain activities or behaviors, when individuals want to vent their feelings then this intelligence is automatically carried out, this depends on the high and low emotional intelligence of the individual.

Employees who have good emotional intelligence will be able to manage emotions themselves and others sequentially to distinguish between them and to use that information to guide their thoughts and actions in carrying out various activities especially in completing work. With a high level of emotional intelligence a person will be able to finish the job well and in accordance with the demands of the organization so that they will be able to improve their career development.

The results of this study are in line with research conducted by Kunnanatt (2008) who found that people who get along well like those who have high emotional intelligence tend to have an advantage over those who have a lower level of emotional intelligence. Excellence here will enhance employee career development. In other words, the higher a person's emotional intelligence will improve his career development.

\section{The Effect of Work Life Balance (X2) on Career Development (X3)}

Work life balance can be seen in conditions where a person can carry out his personal life and work life in a balanced manner. Personal life here is very broad in context as well as in the world of work employees can enjoy time with family such as holidays and gather family, friends, carry out interests and hobbies and carry out other social activities.

By fulfilling this balance, it will have an impact on the performance of someone who will be the main point in the development of his career. Lack of balance of time, involvement and satisfaction will cause a person not motivated at work and unable to complete the job properly. In fact, this proves how important the effect of work life balance is on employee career development.

The results of this study are in line with the research conducted by Caroline Straub (2007) stating that there is a positive effect between Work Life Balance and Career Development especially among women. If work life balance is achieved, it will affect the career development of employees. 
The Effect of Emotional Intelligence (X1) on Organizational Citizenship Behavior ( $Y$ ) and The Effect of Emotional Intelligence (X1) on Organizational Citizenship Behavior (Y) with Career Development as Mediating Variable(X3).

The better a person's emotional intelligence, the higher the employee's organizational citizenship behavior, because emotional intelligence is the ability to control emotions of oneself and others in order to distinguish between them, and to use information to guide thoughts and actions, then from the higher a person's emotional intelligence, the higher the level of organizational citizenship behavior.

After testing 195 employees of PT. Bank Pembangunan Daerah (BPD) Head Office and Main Branch, Padang. The results show that the direct effect of emotional intelligence (X1) on organizational citizenship behavior ( $\mathrm{Y})$ is greater than the effect of emotional intelligence (X1) on organizational citizenship behavior (Y) with career development as mediating variable (X3). In other words, in this study career development mediation has no effect on the relationship of emotional intelligence with employee organizational citizenship behavior that has been built on a conceptual framework. This means that career development does not have an important role in strengthening the relationship of emotional intelligence with Organizational Citizenship Behavior at PT. Bank Pembangunan Daerah (BPD) Head Office and Main Branch, Padang.

This study found that career development cannot be used as a mediating variable so the indirect effects proposed do not need to be examined in subsequent studies.

The Effect of Work Life Balance (X2) on Organizational Citizenship Behavior (Y) and The Effect of Work Life Balance (X2) on Organizational Citizenship Behavior(Y) with Career Development as Mediating Variable (X3).

A person who has a good Work Life Balance is a productive and high-performing worker. In addition, he is also happier and more creative because the outside office environment such as home and friendship and social life outside of work supports his growth. Conversely, if someone does not have a good Work Life Balance, their performance tends to decline and can damage other areas of life. Most of this is due to the high demands of today's work.

After testing 195 employees of PT. Bank Pembangunan Daerah (BPD)Head Office and Main Branch, Padang. The result shows that the direct effect of work life balance (X2) on organizational citizenship behavior $(\mathrm{Y})$ is greater than the effect of work life balance $(\mathrm{X} 2)$ on organizational citizenship behavior $(\mathrm{Y})$ with career development as mediating variable (X3). In other words in this study career development mediation has no effect on the relationship of work life balance with employee organizational citizenship behavior which has also been built on a conceptual framework.

This study also found that career development cannot be used as a mediating variable so the indirect effects proposed do not need to be examined in subsequent studies.

\section{The Effect of Career Development (X3) on Organizational Citizenship Behavior (Y).}

Career is all work carried out by an employee during the period of his work or assignment that provides continuity, order and value for the life of a person or employee. The more a person's career develops, he will always try to do positive and beneficial things for the company that will support the creation of employee organizational citizenship behavior. In this case, career development is seen specifically in career planning, the better employee career planning, the better the behavior of organizational citizenship behavior.

This is supported by the results of research conducted by Erika (2018) stating that there is Career Development that has a significant effect on Organizational Citizenship Behavior. Research conducted by Sutton (2005) also found that career development has a relationship with Organizational Citizenship Behavior. 
Based on the above opinion, it can be concluded that employees who have a developing career will increase the creation of organizational citizenship behavior.

\section{Conclusion}

The result of this study can be seen as follow:

First,Emotional intelligence has significant effect on career development, this case shows that the better employee's emotional intelligence, the higher employee'scareer development.

Second, Work life balance has significant effect on career development, this suggests that the better work life balance of employees, the higher employee's career development.

Third, Career development hassignificant effect on organizational citizenship behavior, this shows that the better career development, the higher organizational citizenship behavior of employees.

Fourth, Emotional intelligence has significant effect on organizational citizenship behavior, which suggests that the better the emotional intelligence, the higher organizational citizenship behavior of employees.

Fifth, Work life balance has significant effect on organizational citizenship behavior, which suggests that the better Work life balance, the higher organizational citizenship behavior of employees.

\section{References}

Carmeli, A., \& Josman, Z. E. (2006). The relationships among emotional intelligence, task performance, and organizational citizenship behaviors. Human Performance. 403-419.

Caroline Straub. (2007). A comparative analysis of the use of work-life practices in Europe Do practices enhance females' career advancement? Institute for Labor Studies, ESADE, Universitat Ramon Llull, Barcelona, Spain.

Daniel Goleman. (2001). Emotional Intelligence to Reach the Peak of Achievement (Translated By Widodo). Jakarta: PT. Gramedia.

Duffy, R. D. \& S. W. E. (2007). The Presence of and search for a calling: Connection to career development. Vocational Behavior Journal.

Erika, et al. (2018). Effects of Compensation and Career Development on Organizational Citizenship Behavior (Study on Employees of PT Woonam Music, Ngoro-Mojokerto). Ournal of Business Administration (JAB), Vol. 55.

Greenhaus, J. H., Collins, K. M., \& Shaw, J. D. (2003). The relationship between work-family balance and quality of life. Journal of Vocational Behavior, 510-531.

Hadizadeh Moghadam, A. and Farajeeyan, M. (2008). The Study of the Effect of Emotional Quotient on the Organizational Citizenship Behavior of the staff with Regard to the Role of Affective Commitment". Message of Management.

Hudson. (2005). The Case for Work-Life Balance. 20:20 Series. E-book The Case for Work / Life Balance: Closing the Gap Between Policy and Practice.

Ibrahim. (2013). The Effect of Emotional Intelligence on Religious Citizenship Behavior and Its Impact on Nurse Performance in Anutapura General Hospital \& Undata Hospital in Palu. E-Jurnal Katalogis, Volume I N, 136-146.

Kunnanatt, J. T. (2008). Emotional intelligence: theory and description A competency model for interpersonal effectiveness. Career Development International. Emerald Group Publishing Limited, Vol. 13 No.

Lockwood, N. R. (2003). Work / LifeBalance: Challenges and Solutions. Quaterly Research, 1-10.

Mojtaba Rafiei. (2017). The Effect of Emotional Quotient on the Organizational Citizenship Behavior in some Iranian Hospitals. Emerald Publihing Limited.

Organ, Dennis W. (2006). Organizational Citizenship Behavior. Its Nature, Antecendents, and 
Consequences. California: Sage Publications, Incle.

Prasetio, A. P. (2016). Effect of work-life balance on Organizational citizenship behavior With mediating variables of job satisfaction and organizational commitment At Bank Rakyat Indonesia, the Bandung regional office. Bandung.

Rabindra, et al. (2016). Effect of Work-Life Balance on Organizational Citizenship Behavior: Role of Organizational Commitment. Global Business Review, 17.

Robbins. (2007). Organizational behavior. Jakarta: Salemba Empat.

Robbins \& Judge. (2008).Organizational behavior. (Book 2). Jakarta: Salemba Empat.

Siagian, S. P. (2012). Human Resource Management. Jakarta: Bumi Aksara.

Sutton, M. J. (2005). Organizational citizenship behavior: A career development strategy. Graduate Theses and Dissertations.

Weckstein, S. H. (2008a). How To Practice The Art Of Life Balance. E-book. Copyright: Stacey Weckstein Hoffer.

Weckstein, S. H. (2008b). How To Practice The Art Of Life Balance. E-book. Copyright: Stacey Weckstein Hoffer. 